Agr. Biol. Chem., 38 (2), 443 454, 1974

\title{
Purification and Properties of $\alpha$-Glucosidase from Bacillus cereus
}

\author{
Yoshiki YamaSAKI and Yukio SuzUKI \\ Institute for Agricultural and Biological Sciences, Okayama University, Kurashiki, Okayama-ken \\ Received September 14, 1973

\begin{abstract}
a-Glucosidase has been isolated from Bacillus cereus in ultracentrifugally and electrophoretically homogeneous form, and its properties have been investigated. The enzyme has a sedimentation constant of $1.4 \mathrm{~S}$ and a molecular weight of 12,000 . The highly purified enzyme splits $\alpha$-D-( $1 \rightarrow 4)$-glucosidic linkages in maltose, maltotriose, and phenyl $\alpha$-maltoside, but shows little or no activity toward polysaccharides, such as amylose, amylopectin, glycogen and soluble starch. The enzyme has $\alpha$-glucosyltransferase activity, the main transfer product from maltose being maltotriose. The enzyme can also catalyze the transfer of $\alpha$-glucosyl residue from maltose to riboflavin. On the basis of inhibition studies with diazonium-1- $\mathrm{H}-$ tetrazole, rose bengal and $p$-chloromercuribenzoate, it is assumed that the enzyme contains both histidine and cysteine residues in the active center.
\end{abstract}

In the previous papers, ${ }^{1,2)}$ we reported the purification, crystallization and properties of an $\alpha$-glucosidase from the mycelia of $M$ ucor javanicus. There have been far fewer studies on $\alpha$-glucosidase from bacteria than on $\alpha$ glucosidases from molds and yeast. Crude or partially purified preparations have so far been used in the studies on the bacterial $\alpha$-glucosidase. In the course of our investigations on the nature of $\alpha$-glucosidases from microorganisms, an $\alpha$-glucosidase was isolated in a highly purified form from a bacterium which was isolated from soil and identified to be Bacillus cereus. It was found that the values of the sedimentation constant and the molecular weight of the $\alpha$-glucosidase were considerably lower than those which were reported for other glycosidases. ${ }^{3)}$ This $\alpha$-glucosidase was different in the substrate specificity and the transglucosylation action from other $\alpha$ glucosidases. The enzyme catalyzed also the synthesis of riboflavin $\alpha$-glucoside from maltose and riboflavin. The present paper deals with the purification and the properties of this a-glucosidase.

\section{MATERIALS AND METHODS}

\section{Microorganism}

About 30 strains of bacteria were isolated from soil in our laboratory by repeating a plate culture with a medium containing $3 \%$ maltose (technical grade), $0.5 \%$ peptone, $0.2 \% \mathrm{~K}_{2} \mathrm{HPO}_{4}, 0.03 \% \mathrm{MgSO}_{4} \cdot 7 \mathrm{H}_{2} \mathrm{O}$, $0.01 \% \mathrm{CaCl}_{2} \cdot 2 \mathrm{H}_{2} \mathrm{O}$ and $2 \%$ agar in tap water, and being adjusted to $\mathrm{pH}$ 7.0. These strains were grown aerobically at $30^{\circ} \mathrm{C}$ for $16 \mathrm{hr}$ in $100 \mathrm{ml}$ of the following medium: $1 \mathrm{~g}$ of glycerol, $0.5 \mathrm{~g}$ of maltose (technical grade), $0.5 \mathrm{~g}$ of yeast extract, $0.5 \mathrm{~g}$ of peptone, $0.2 \mathrm{~g}$ of $\mathrm{K}_{2} \mathrm{HPO}_{4}, 0.03 \mathrm{~g}$ of $\mathrm{MgSO}_{4} \cdot 7 \mathrm{H}_{2} \mathrm{O}$ and $0.01 \mathrm{~g}$ of $\mathrm{CaCl}_{2} \cdot 2 \mathrm{H}_{2} \mathrm{O}$ were dissolved in $100 \mathrm{ml}$ of tap water and adjusted to pH 7.0. After incubation, the cells were harvested by centrifugation, washed, and suspended in deionized water to give a cell concentration of $8 \%$ (wet weight). The procedure used for the estimation of the $a$-glucosidase activity of the strains was the same as that given under enzyme assays 1) and 2) in analytical techniques except for the replacement of enzyme with $0.1 \sim 1 \mathrm{ml}$ of the cell suspension. One strain was selected from the isolated strains, on the basis of the activities of both maltose decomposition and riboflavin $a$-glucoside formation. This strain was identified as Bacillus cereus in the following ways:

(a) Morphological characters: Vegetative cell, rods, 1.0 to 1.2 by 3.0 to $5.0 \mu$, with rounded ends. Occurring singly or in short chains on bouillon agar, in long chains on soy bean agar. Gram-positive. Motile. Spore, ellipsoidal to short cylindrical, 1.0 to 1.2 by 1.2 to $2.0 \mu$. Para-central to subterminal. Many spores were formed in $24 \mathrm{hr}$. Sporangia, not appreciably swollen.

(b) Cultural characters: Gelatin stab: Liquefaction small crateriform at first, then becoming stratiform. Gelatin agar streak plate: Wide zone of hydrolysis. Agar slants: Growth thin to moderate, rough, opaque, somewhat whitish, non-adherent, spreading, irregular edged with arborescent outgrowth. Glucose agar slants: Growth abundant, heavier and softer than on 
agar. Glucose nitrate agar slants: Scant growth. Tyrosine agar slants: Growth moderate with arborescent outgrowth. Soy bean agar slants: Growth much abundant, whitish, very widely spreading by means of long, sometimes few paralleled, curled chains of cells, turning to the left or right. Milk agar streak plate: Wide zone of hydrolysis of casein. Potato: Growth abundant, spreading, somewhat raised, soft, creamy white. Glucose asparagine agar slants: Growth abundant, whitish, rough, irregular edged with few arborescent outgrowth. Broth: Heavy, uniform turbidity with soft, easily dispersed sediment and with soft ring pellicle. Milk: Peptonized after slight coagulation.

(c) Physiological characters: Acid but no gas (with ammonium salts as source of nitrogen) from glucose and sucrose. No acid from mannitol, arabinose or xylose. All of starch hydrolysis, acetylmethylcarbinol production, citrate utilization as sole source of carbon, nitrate reduction, and methylene blue reduction were positive. Indole production, negative. Oxygen demand: Aerobic, facultatively anaerobic.

(d) Pathogenicity: Non-pathogenic.

The above-mentioned properties of the selected strain were found to be identical with those of $B$. cereus, described in Bergey's Manual.

\section{Culture}

The medium used for maintaining and culturing $B$. cereus had the following composition (figures in $g$ per liter): glycerol, 10; maltose (technical grade), 5; peptone, 10 ; yeast extract, $2 ; \mathrm{K}_{2} \mathrm{HPO}_{4}, 2 ; \mathrm{MgSO}_{4}$. $7 \mathrm{H}_{2} \mathrm{O}, 0.3$; and $\mathrm{CaCl}_{2} \cdot 2 \mathrm{H}_{2} \mathrm{O}, 0.1$. B. cereus was picked up from the agar slant of the medium, and inoculated into $500 \mathrm{ml}$-shaking flasks containing $80 \mathrm{ml}$ of the medium. The incubation was carried out at $30^{\circ} \mathrm{C}$ for $24 \mathrm{hr}$ on a reciprocating shaker (68 strokes per min, $9 \mathrm{~cm}$ amplitude), and $160 \mathrm{ml}$ of a $24 \mathrm{hr}$ culture was used as an inoculum into a 30 liter jar fermenter (rotation of impeller at $300 \mathrm{rpm}$ and aeration at 15 liters per minute) containing 16 liters of the medium. After incubation at $30^{\circ} \mathrm{C}$ for 2 days, the bacterial cells from four jar fermenters were harvested by centrifugation. The yield of cells was $1860 \mathrm{~g}$, on wet weight basis.

\section{Chemicals and reagents}

The markers for the determination of the molecular weight were obtained from Schwarz Mann Inc., (Orangeburg, New York, U.S.A.). Other chemicals and reagents used were the same as described in the previous papers. ${ }^{1,2}$ )

\section{Analytical techniques}

Enzyme assays

1) Assav for a-glucosidase artivitu. was used as substrate, the standard reaction mixture contained $0.1 \mathrm{ml}$ of $1 \%$ maltose aqueous solution, $0.25 \mathrm{ml}$ of $0.1 \mathrm{M}$ phosphate buffer, pH 6.9, enzyme solution, and deionized water in a final volume of $0.5 \mathrm{ml}$. After incubation for $15 \mathrm{~min}$ at $37^{\circ} \mathrm{C}$, the reaction was stopped by heating the mixture in a boiling water bath for $5 \mathrm{~min}$. The amount of glucose formed was determined according to the method of Papadopoulas et al., as modified by Dahlquist.5) One unit of $a$ glucosidase activity was defined as the amount of enzyme which formed $1 \mu$ mole of glucose from maltose under the conditions described above. Phenol was determined by the method of Folin and Ciocalteu. ${ }^{6}$

2) Assay for a-glucosyltransferase activity. In the standard assay, the activity was determined by measuring the transfer of $a$-glucosyl residue from maltose to riboflavin. The reaction mixture contained $2 \mathrm{ml}$ of $5 \%$ maltose aqueous solution, $5 \mathrm{ml}$ of $0.06 \%$ riboflavin in $0.1 \mathrm{M}$ phosphate buffer, $\mathrm{pH} 6.9$, enzyme solution, and deionized water in a final volume of $10 \mathrm{ml}$. After incubation at $37^{\circ} \mathrm{C}$ for $30 \mathrm{~min}$, the reaction was stopped by heating the mixture for $5 \mathrm{~min}$ in a boiling water bath. The amount of riboflavin a-glucoside formed in the reaction mixture was estimated by paper chromatography, as described in the previous paper. ${ }^{11}$

\section{Protein determination}

The protein concentration was determined by measuring absorbances at $260 \mathrm{~nm}$ and $280 \mathrm{~nm}^{71}$ The protein concentration of each fraction from a column was followed by measuring the absorbance at $280 \mathrm{~nm}$ with a Hitachi Perkin-Elmer model 139 spectrophotometer.

\section{Ultracentrifugal analysis}

Ultracentrifugal studies were performed with a Hitachi model 282 analytical ultracentrifuge.

\section{Disc gel electrophoresis}

The electrophoresis of the enzyme was carried out in a polyacrylamide gel, $\mathrm{pH} 9.0$, by the method of Davis. ${ }^{8}$ After the run, the gel was stained for proteins with $1 \%$ Amido Black $10 \mathrm{~B}$ in $7 \%$ acetic acid and destained with $7 \%$ acetic acid.

\section{Determination of isoelectric point}

Isoelectric focusing experiments were carried out at $4^{\circ} \mathrm{C}$ in a column of $110 \mathrm{ml}$ capacity of an LKB 8100 ampholine electrofocusing equipment, as described previously. ${ }^{11}$

\section{Determination of molecular weight}

For the determination of the molecular weight, the enzvme was subiected to electronhnrecic hv the method 
of Weber et al., ${ }^{10)}$ with the use of polyacrylamide gel containing sodium dodecyl sulfate at a concentration of 0.1 per cent. After electrophoresis, the distances (in $\mathrm{cm}$ ) which the marker proteins moved were plotted against the logarithms of their molecular weights. The molecular weight of the purified enzyme was determined from its relative mobilities with the aid of this plot. The markers used were horse heart cytochrome $c$ (mol. wt. 12,400), lysozyme (mol. wt. 14,307), sperm whale myoglobin (mol. wt. 17,800), beef pancreas chymotrypsinogen A (mol. wt. 25,000), ovalbumin (mol. wt. 45,000), and bovine serum albumin ( $\mathrm{mol}$. wt. 67,000).

\section{RESULTS}

\section{Isolation of enzyme}

Unless otherwise indicated, operations were carried out at $4^{\circ} \mathrm{C}$. An outline of the purification procedure and the results obtained are given in Table I.

Step 1: Preparation of crude extract. The cells $(1860 \mathrm{~g})$ were suspended in 3.7 liters of $0.05 \mathrm{M}$ phosphate buffer, $\mathrm{pH} 6.9$, containing $1 \mathrm{~mm}$ mercaptoethanol. The suspension was crushed out with a Ōtake model 5615 french press (Tokyo, Japan). The intact cells and debris were removed by centrifugation at $14,310 \times g$ for $20 \mathrm{~min}$.

Step 2: First ammonium sulfate fractionation. To the crude extract was added solid ammonium sulfate to $50 \%$ saturation. After $30 \mathrm{~min}$, the resultant precipitate was removed by centrifugation and discarded. The su- pernatant solution was then brought to $100 \%$ saturation by the further addition of solid ammonium sulfate. After standing overnight, the precipitate was collected by centrifugation at $14,310 \times g$ for $20 \mathrm{~min}$, and dissolved in $0.05 \mathrm{M}$ phosphate buffer, $\mathrm{pH} 6.9$, containing $1 \mathrm{~mm}$ mercaptoethanol. The solution was dialyzed overnight against $0.02 \mathrm{M}$ phosphate buffer, pH 6.9, containing $1 \mathrm{mM}$ mercaptoethanol.

Step 3: DEAE-cellulose column chromatography. DEAE-cellulose was packed into two columns $(4 \phi \times 22 \mathrm{~cm})$ and equilibrated with $0.05 \mathrm{M}$ Tris- $\mathrm{HCl}$ buffer, $\mathrm{pH} 7.0$, containing $1 \mathrm{~mm}$ mercaptoethanol. The dialyzed preparation was divided into two portions and each portion was applied to a separate column. Elution was carried out with a linear gradient of increasing concentration of sodium chloride (from 0 to $0.5 \mathrm{M}$ ) in the same buffer (Fig. 1). The activity appeared in Fractions 102 to 112. To the combined eluate was added solid ammonium sulfate to $100 \%$ saturation, and the solution was allowed to stand for $30 \mathrm{~min}$. The precipitate formed was collected by centrifugation, and dissolved in $0.05 \mathrm{M}$ phosphate buffer, $\mathrm{pH} 6.9$, containing $1 \mathrm{~mm}$ mercaptoethanol. The solution was dialyzed overnight against $0.02 \mathrm{M}$ phosphate buffer, $\mathrm{pH} 6.9$, containing $1 \mathrm{~mm}$ mercaptoethanol.

Step 4: Second ammonium sulfate fractionation. To the dialyzed preparation from Step

Table I. Purification of Enzyme from $B$. cerelus

\begin{tabular}{|c|c|c|c|c|c|}
\hline \multirow{2}{*}{ Step } & \multicolumn{2}{|c|}{ Protein } & \multicolumn{3}{|c|}{$\alpha$-Glucosidase } \\
\hline & $\mathrm{mg}$ & $280 \mathrm{~nm} / 260 \mathrm{~nm}$ & Unit & S.A. ${ }^{a\}}$ & Recov. \% \\
\hline 1. Crude extract & 131,580 & 0.66 & 738,263 & 5.6 & 100 \\
\hline $\begin{array}{l}\text { 2. Ammonium sulfate fractionation, } \\
\text { saturation } 50 \sim 100 \%\end{array}$ & 31,200 & 0.61 & 573,813 & 18.4 & 77.7 \\
\hline 3. DEAE-cellulose chromatography & $1,544.7$ & 1.21 & 180,800 & 117.0 & 24.5 \\
\hline $\begin{array}{l}\text { 4. Ammonium sulfate fractionation, } \\
\text { saturation } 60 \sim 70 \% \\
\text { 5. DEAE-Sephadex A-25 }\end{array}$ & 568.7 & 1.69 & 107,143 & 188.4 & 14.5 \\
\hline chromatography & 142.3 & 1.59 & 28,139 & 197.7 & 3.8 \\
\hline 6. Preparative disc gel electrophoresis & 22.1 & 0.77 & 1,855 & 83.9 & 0.3 \\
\hline
\end{tabular}

a) Unit/protein (mg). 


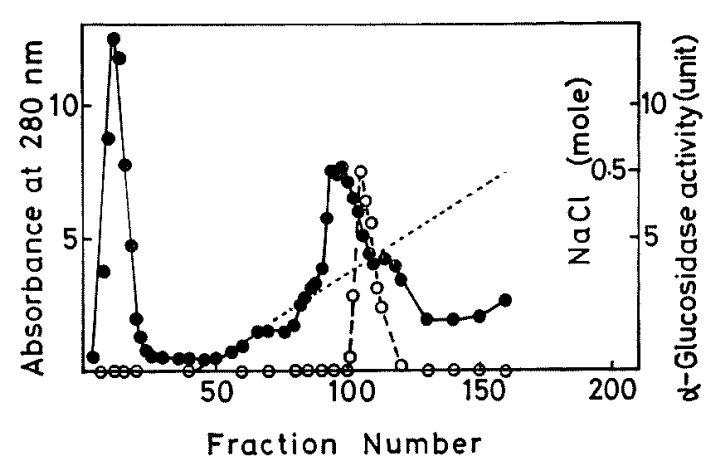

Fig. 1. DEAE-cellulose Column Chromatography.

Applied protein: $\quad 15,600 \mathrm{mg}$.

Flow rate: about $45 \mathrm{ml}$ per hour.

Fraction volume: $15 \mathrm{ml}$.

- - absorbance at $280 \mathrm{~nm} ; 0-.0$, a-glucosidase activity per $0.01 \mathrm{ml}$ of each fraction.

3 was added solid ammonium sulfate to $60 \%$ saturation. After $30 \mathrm{~min}$, the precipitate was removed by centrifugation, and then more solid ammonium sulfate was added to $70 \%$ saturation. After standing overnight, the precipitate was collected by centrifugation and dissolved in $0.05 \mathrm{M}$ phosphate buffer, $\mathrm{pH} 6.9$, containing $1 \mathrm{~mm}$ mercaptoethanol. The solution was dialyzed overnight against $0.02 \mathrm{M}$ phosphate buffer, $\mathrm{pH} 6.9$, containing $1 \mathrm{~mm}$ mercaptoethanol.

Step 5: DEAE-Sephadex column chromatography. The dialyzed solution was then applied to a column of DEAE-Sephadex A-25 $(2.8 \phi \times 19 \mathrm{~cm})$ which had been equilibrated with $0.05 \mathrm{M}$ Tris- $\mathrm{HCl}$ buffer, $\mathrm{pH} 7.0$, containing $1 \mathrm{~mm}$ mercaptoethanol. Elution was carried out with the same buffer to which was added $\mathrm{NaCl}$. The concentration of $\mathrm{NaCl}$ was increased in a stepwise fashion (Fig. 2). The active fractions (No. 75 to 99) were collected, and precipitated by the addition of solid ammonium sulfate to $100 \%$ saturation. The precipitate was collected by centrifugation and dissolved in $0.05 \mathrm{~m}$ phosphate buffer, $\mathrm{pH} 6.9$, containing $1 \mathrm{~mm}$ mercaptoethanol. The solution was dialyzed overnight against $0.02 \mathrm{M}$ phosphate buffer, $\mathrm{pH} 6.9$, containing $1 \mathrm{~mm}$ mercaptoethanol.

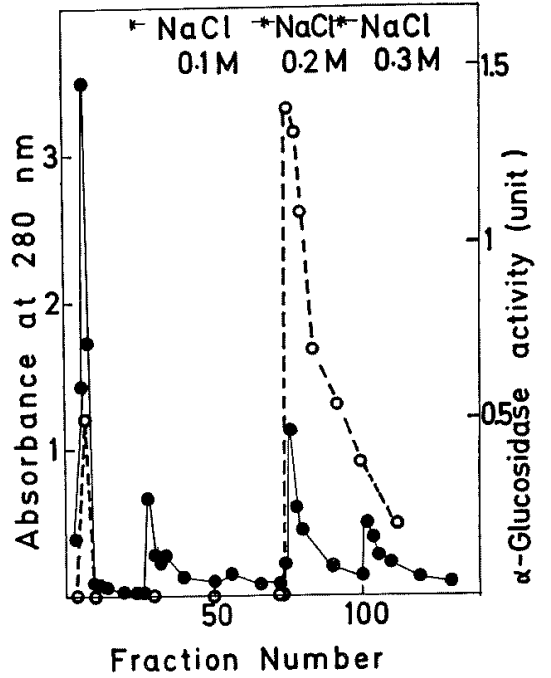

FIG. 2. DEAE-Sephadex A-25 Column Chromatography.

Applied protein: $568.7 \mathrm{mg}$. Flow rate: about $45 \mathrm{ml}$ per hour. Fraction volume: $15 \mathrm{ml}$.

- - , absorbance at $280 \mathrm{~nm} ; 0--0, a$-glucosidase activity per $0.01 \mathrm{ml}$ of each fraction.

Step 6: Preparative disc gel electrophoresis. The dialyzed preparation was subjected to preparative disc gel electrophoresis. The equipment was made up of a running column $(6.8 \phi \times 15 \mathrm{~cm})$ and two buffer reservoirs. The running column was composed of $90 \mathrm{ml}$ of a spacer gel and $360 \mathrm{ml}$ of a separating gel. The concentration of acrylamide was $2.5 \%$ in the spacer gel and $7.0 \%$ in the separating gel, respectively. Each of the upper and lower reservoirs contained $1000 \mathrm{ml}$ of buffer. The gels and the electrode buffer were prepared by the same method as that of D. E. Williams et al., ${ }^{9)}$ except that mercaptoethanol was added to both gels and buffer in concentration of $3 \mathrm{mM}$ in order to preserve the enzyme activity. The dialyzed preparation was divided into 10 portions. To each portion was added sucrose to a final concentration of $20 \%$, and the mixture was layered on the surface of the spacer gel. Electrophoresis was carried out with the anode in the lower reservoir by applying a constant current of $60 \mathrm{~mA}$. The electrode buffer was replaced by the new buffer at 3-hr intervals. The run was carried out until the blue tracking 
disc of the indicator dye (bromphenol blue) had reached the one-quarter of the length of the separating gel from the end. The electrophoretic mobility of the active protein band was slightly slower than that of the indicator dye. The gel was removed from the running column, and cut into 3 to $5 \mathrm{~mm}$ sections. Each of the gel sections was homogenized with about $20 \mathrm{ml}$ of $0.2 \mathrm{M}$ phosphate buffer, $\mathrm{pH}$ 6.9. After standing for $30 \mathrm{~min}$, the enzymatically active homogenates were combined, and filtered to remove the gel particles. The filtrate was dialyzed overnight against $0.02 \mathrm{~m}$ phosphate buffer, $\mathrm{pH} 6.9$, containing $1 \mathrm{~mm}$ mercaptoethanol, and concentrated by ultrafiltration using a collodion bag. This concentrate was used as the purified enzyme. The dye showing absorption at 260 and $280 \mathrm{~nm}$ was not removed from the purified enzyme solution by the procedures of dialysis and ammonium sulfate precipitation. There- fore, the presence of the dye might be a cause for the result that the ratio of absorptions at 280 and $260 \mathrm{~nm}$ and the specific activity of the enzyme solution obtained from Step 6 in Table I were lower than those of Step 5.

\section{Criteria of purity}

1) Ultracentrifugal pattern. The sedimentation pattern of the purified enzyme is shown in Fig. 3. The boundary of the enzyme moved showing a single and symmetrical peak. The value of $s_{20, w}^{0}$ was calculated as being $1.4 \mathrm{~S}$ (Fig. 4).

2) Disc gel electrophoresis. When the purified enzyme was subjected to electrophoresis in a polyacrylamide gel at $\mathrm{pH}$ 9.5, a single band of protein migrating toward the anode was observed. No contaminants were detected (Fig. 5).
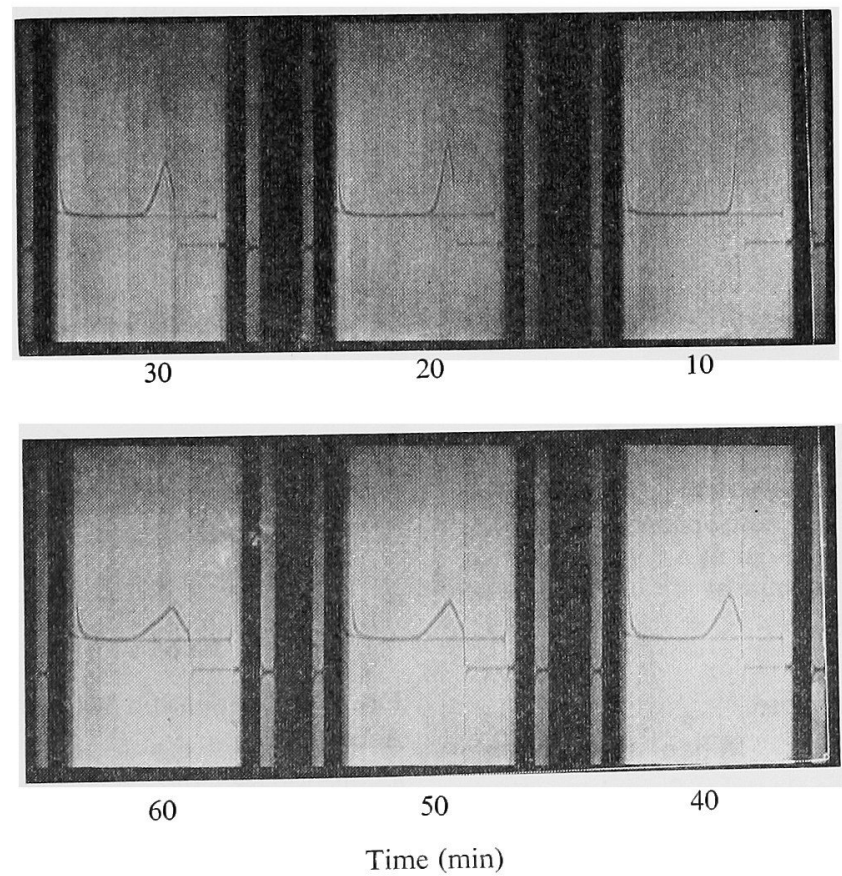

FIG. 3. Sedimentation Pattern of $a$-Glucosidase.

Ultracentrifugation of $a$-glucosidase was carried out at a concentration of $0.5 \%$ in $0.02 \mathrm{M}$ phosphate buffer, pH 6.9. Experimental conditions: temperature, $20.0^{\circ} \mathrm{C}$; speed, $58,000 \mathrm{rpm}$; cell used, a standard $12 \mathrm{~mm}$ double sector cell. The photographs were taken at indicated times after the maximum speed had been reached. 


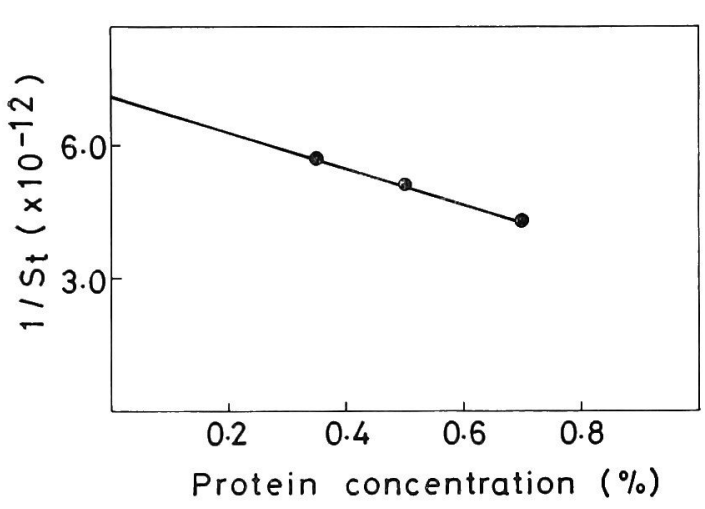

FIG. 4. Concentration Dependence of Sedimentation Constant of $a$-Glucosidase.

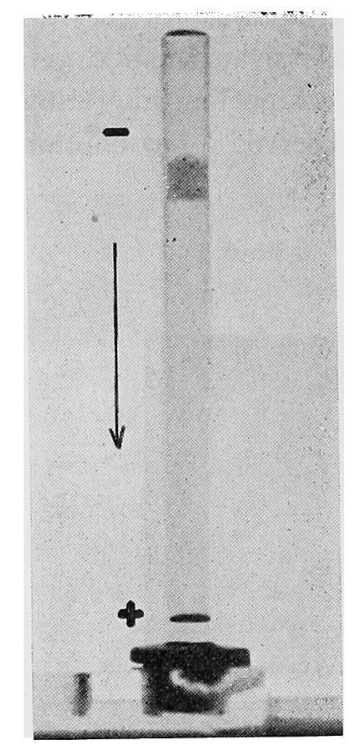

FIG. 5. Disc Electrophoresis of $a$-Glucosidase.

The purified enzyme protein $(200 \mu \mathrm{g})$ was applied to polyacrylamide disc gel electrophoresis at $\mathrm{pH} 9.5$. Electrophoresis was carried out at a constant current of $5 \mathrm{~mA}$ per tube for $90 \mathrm{~min}$ at $4^{\circ} \mathrm{C}$. Tris-glycine buffer, pH 8.3, was used.

\section{Properties of enzyme}

1) Isoelectric point. When the enzyme was subjected to isoelectric focusing, there appeared a single absorbance peak. The isoelectric point of this enzyme was at $\mathrm{pH} 4.5$.

2) Molecular weight. The molecular weight of the enzyme, which was determined by sodium dodecyl sulfate-polyacrylamide gel electrophoresis, was 12,000 (Fig. 6).

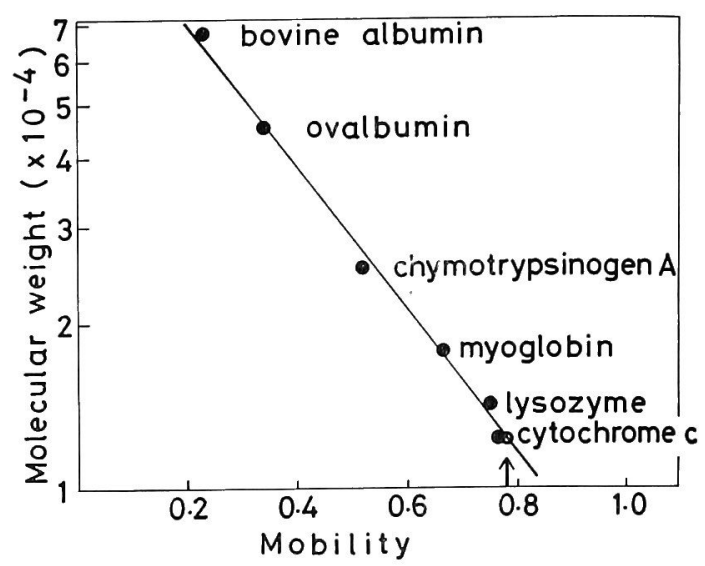

FIG. 6. Determination of the Molecular Weight of $a$-Glucosidase.

The marker proteins used were bovine albumin, ovalbumin, chymotrypsinogen A, myoglobin, lysozyme, and cytochrome $c$. All proteins were run on duplicate gels. The arrow indicates the mobility of $a$-glucosidase. The extrapolated value for $a$ glucosidase is 12,000 .

3) Linearity of the enzyme activity. A linear relationship between the protein concentration and both enzyme activities was observed (Fig. 7).

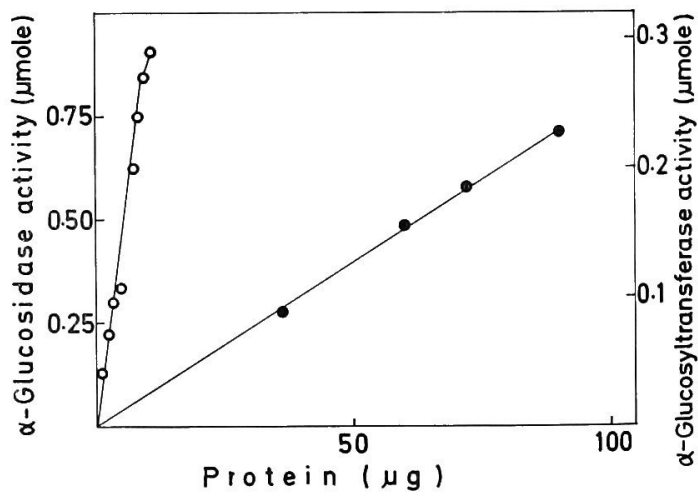

FIG. 7. Relationship between Enzyme Protein and Activities.

$a$-Glucosidase and $a$-glucosyltransferase activities were estimated using various amounts of enyzme under the standard assay conditions.

$\mathrm{O}-\mathrm{O}, a$-glucosidase activity in a final volume of $0.5 \mathrm{ml}$; $-a$-glucosyltransferase activity in a final volume of $2.5 \mathrm{ml}$.

4) $p H$ Optimum. As shown in Fig. 8, the $\mathrm{pH}$ optimum for the $\alpha$-glucosidase activity 
laid at 6.8 to 7.3 .

5) pH stability. No loss in the $\alpha$-glucosidase activity was observed at the $\mathrm{pH}$ range of 6.8 to 7.3 (Fig. 9).

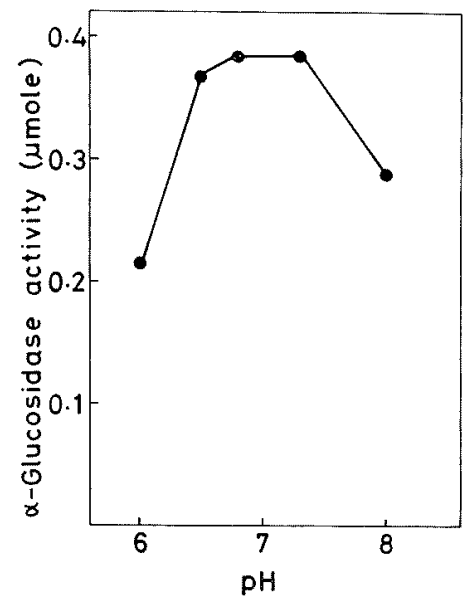

FIG. 8. Effect of pH on the Enzyme Activity.

$a$-Glucosidase activity was estimated using $0.02 \mathrm{ml}$ of enzyme solution ( 0.38 units) at various pH. Phosphate buffer was used. For other assay conditions see MATERIALS AND METHODS.

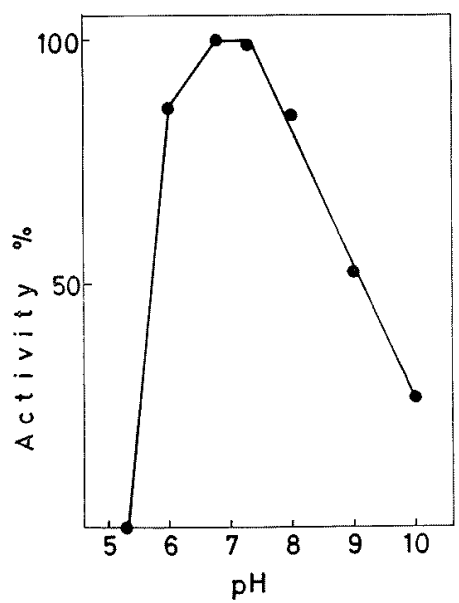

FIG. 9. pH Stability of the Enzyme.

The enzyme solution $(0.04 \mathrm{ml}, 0.76$ units $)$ was preincubated for $20 \mathrm{hr}$ at $30^{\circ} \mathrm{C}$ with $0.2 \mathrm{ml}$ of different buffer: $0.05 \mathrm{M}$ acetate buffer, $\mathrm{pH} 4.0$ to $6.0 ; 0.05 \mathrm{M}$ phosphate buffer, $\mathrm{pH} 6.0$ to $8.0 ; 0.05 \mathrm{M}$ veronal buffer, pH 7.0 to $9.0 ; 0.05 \mathrm{M}$ glycine- $\mathrm{NaOH}$ buffer, $\mathrm{pH} 9.0$ to 10.0 .

After adjustment of $\mathrm{pH}$ with $0.2 \mathrm{M}$ phosphate buffer, $\mathrm{pH} 6.9$, the residual $a$-glucosidase activity was measured under the standard assay conditions.
6) Temperature optimum. The temperature optimum for the $\alpha$-glucosidase activity was observed to be at $40^{\circ} \mathrm{C}$ (Fig. 10).

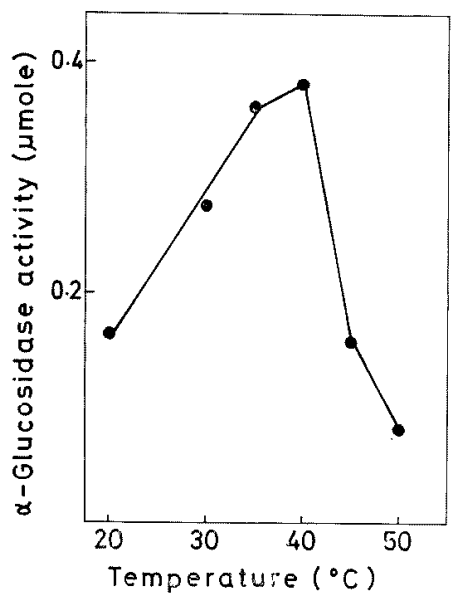

FIG. 10. Effect of Temperature on the Enzyme Activity.

$a$-Glucosidase activity was estimated using $0.02 \mathrm{ml}$ of enzyme solution ( 0.38 units) at various temperature. For other assay conditions see MATERIALS AND METHODS.

7) Heat stability. As shown in Fig. 11, the enzyme was stable up to $35^{\circ} \mathrm{C}$, whereas above this temperature its activity was markedly decreased.

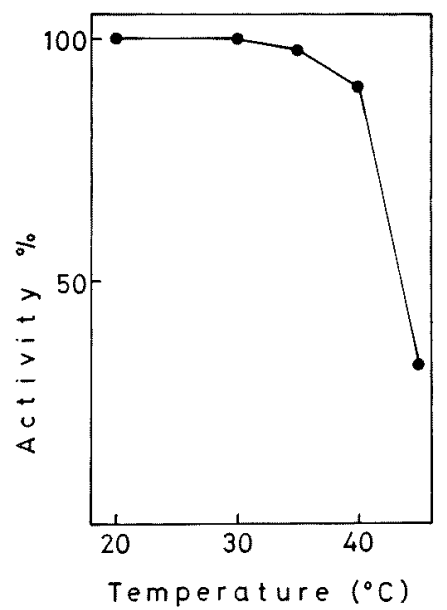

FIG. 11. Heat Stability of the Enzyme.

The reaction mixture containing $0.04 \mathrm{ml}$ of enzyme solution ( 0.76 units) and $0.36 \mathrm{ml}$ of $0.05 \mathrm{M}$ phosphate buffer, $\mathrm{pH}$ 6.9, was preincubated for $15 \mathrm{~min}$ at various temperatures.

After preincubation, the residualo-glucosidase activity was measured under the standard assay conditions. 
8) Substrate specificity. With various substrates, the $\alpha$-glucosidase activity of the enzyme was examined, and the relative rates of hydrolysis were listed in Table II. Maltose, nigerose, phenyl $\alpha$-maltoside, and maltotriose were readily served, but isomaltose, kojibiose, sucrose, soluble starch, glycogen, or amylose was very slightly susceptible or resistant to the enzyme. No enzyme activity was observed with maltitol, maltotriitol, cellobiose, melibiose, lactose, or raffinose.

\section{Table II. Substrate Specificity OF THE ENZYME}

The reaction mixture containing $0.04 \mathrm{ml}$ of enzyme solution ( 0.76 units), $5.55 \mathrm{~mm}$ substrate and $50 \mathrm{~mm}$ phosphate buffer, $\mathrm{pH} 6.9$, in a final volume of $0.5 \mathrm{ml}$ was incubated at $37^{\circ} \mathrm{C}$ for $15 \mathrm{~min}$. The reaction was stopped by heating for $5 \mathrm{~min}$ in a boiling water bath for the estimation of glucose liberated.

\begin{tabular}{|c|c|}
\hline Substrate & $\begin{array}{c}\text { Hydrolysis } \\
\text { (relative rate \%) }\end{array}$ \\
\hline Methyl a-glucoside & 0 \\
\hline Phenyl a-glucoside & trace \\
\hline Isomaltose & trace \\
\hline Kojibiose & 0 \\
\hline Maltose & 100 \\
\hline Nigerose & 62.5 \\
\hline Sucrose & 0 \\
\hline Trehalose & 0 \\
\hline Turanose & 0 \\
\hline Phenyl $a$-maltoside & 46.6 \\
\hline Maltotriose & 26.5 \\
\hline Panose & 0 \\
\hline Soluble starch ${ }^{a}$ & 0 \\
\hline Glycogen $^{a}$ & 0 \\
\hline Amylose $\mathrm{e}^{a}$ & 0 \\
\hline Amylopectina & 0 \\
\hline Cellobiose & 0 \\
\hline Lactose & 0 \\
\hline
\end{tabular}

a) $0.1 \mathrm{ml}$ of $1 \%$ substrate was used.

9) Pattern of action on phenyl $\alpha$-maltoside. As shown in Fig. 12, the enzyme hydrolyzed phenyl $\alpha$-maltoside to glucose and phenyl $\alpha$-glucoside.

10) Michaelis constant. The value of $\mathrm{Km}$ for maltose was calculated to be $5.55 \times$ $10^{-3} \mathrm{M}$ from the Lineweaver-Burk plot (Fig. 13).

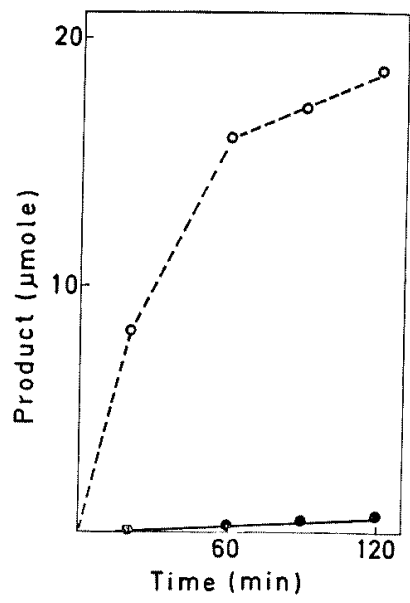

FIG. 12. Pattern of Action on Phenyl $a$-Maltoside.

The reaction mixture $(5 \mathrm{ml})$ containing $0.3 \mathrm{ml}$ of enzyme solution (5.7 units), $0.5 \mathrm{ml}$ of $2 \%$ substrate and $4.2 \mathrm{ml}$ of $0.05 \mathrm{M}$ phosphate buffer, $\mathrm{pH} 6.9$, was incubated at $37^{\circ} \mathrm{C}$. For estimation of glucose liberated, a portion of the reaction mixture was pipetted out at various time intervals and heated in a boiling water bath for $5 \mathrm{~min}$. For estimation of phenol liberated, $0.5 \mathrm{ml}$ of the reaction mixture was pipetted out at various time intervals, and the reaction was stopped by pouring into $2 \mathrm{ml}$ of $5 \% \mathrm{Na}_{2} \mathrm{CO}_{3}$.

○-- $\bigcirc$, glucose liberated; - phenol liberated.

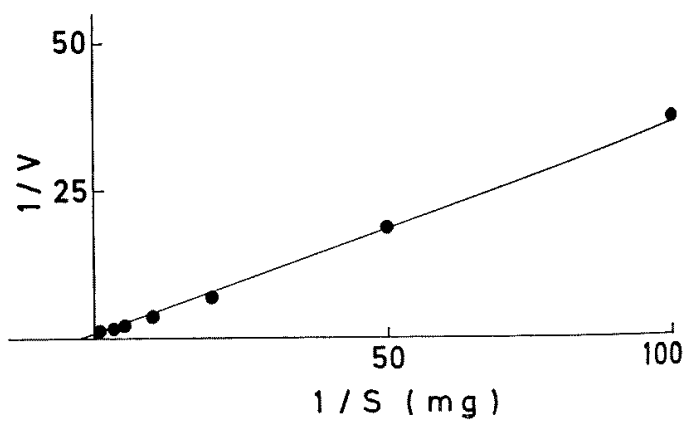

Fig. 13. Effect of Maltose Concentration on aGlucosidase.

For the estimation of $\mathrm{Km}$ value, the reaction mixture containing $0.03 \mathrm{ml}$ of enzyme solution ( 0.57 units), $0.2 \mathrm{ml}$ of $0.1 \mathrm{M}$ phosphate buffer, $\mathrm{pH} 6.9$, indicated amounts of maltose, and deionized water in a final volume of $0.5 \mathrm{ml}$ was incubated at $37^{\circ} \mathrm{C}$ for $30 \mathrm{~min}$. Velocity (V) was expressed as increased absorbance at $420 \mathrm{~nm}$ of the reaction mixture, and substrate concentration (S) as $\mathrm{mg}$ per $0.5 \mathrm{ml}$ of the reaction mixture.

11) Transfer reaction products. When the enzyme was incubated with $5 \%$ maltose, two unknown substances (temporarily named 


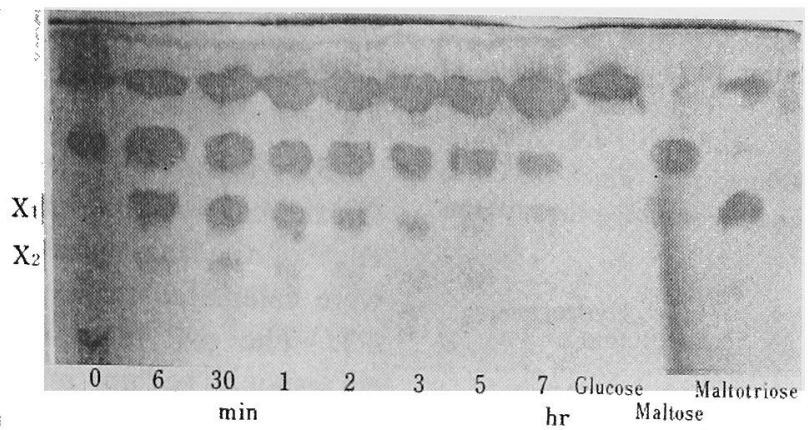

Fig. 14. A Paper Chromatogram of Transglucosylation Products from Maltose.

The reaction mixture $(3 \mathrm{ml})$ containing $0.75 \mathrm{ml}$ of enzyme solution (concentrated solution, 142.5 units), $1.5 \mathrm{ml}$ of $10 \%$ maltose, and $0.75 \mathrm{ml}$ of $0.2 \mathrm{M}$ phosphate buffer, pH 6.9 , was incubated at $37^{\circ} \mathrm{C}$. At various time intervals, $0.1 \mathrm{ml}$ of the reaction mixture was applied on a Toyo No. 2 filter paper, and developed three times by the ascending method with $n$-butanol-pyridine-water $(6: 4: 3, v / v)$. After drying, the spots were made visible by the silver nitrate dip method.

$\mathrm{X}_{1}$ and $\mathrm{X}_{2}$ ) which were chromatographically different from either glucose or maltose, were detected on a paper chromatogram (Fig. 14). The unknown substance $X_{1}$ was isolated and characterized by the following procedure. The reaction mixture containing $1 \mathrm{ml}$ of $10 \%$ maltose, $0.5 \mathrm{ml}$ of $0.2 \mathrm{M}$ phosphate buffer, $\mathrm{pH} 6.9,0.2 \mathrm{ml}$ of the purified enzyme solution (95.44 units), and deionized water in a final volume of $2 \mathrm{ml}$ was incubated at $37^{\circ} \mathrm{C}$ for $60 \mathrm{~min}$. The reaction was stopped by heating the mixture in a boiling water bath for $5 \mathrm{~min}$. All of the reaction mixture was applied on a sheet of filter paper (Toyo No. 2 filter paper, $30 \times 60 \mathrm{~cm})$ in a straight line, and developed three times with $n$-butanol-pyridine-water $(6: 4: 3, v / v)$ by the ascending method. The sheet of paper was cut out in a band at the position corresponding to the spot of $X_{1}$, which had been determined with a guide strip. $\mathrm{X}_{1}$ was then extracted with deionized water from the band, and the extract was concentrated under reduced pressure. The concentrate showed a single reducing spot on the paper chromatogram. The position of $\mathrm{X}_{1}$ on the chromatogram was similar to that of maltotriose, but not to that of kojibiose or nigerose. When $0.3 \mathrm{ml}$ of the concentrate of $\mathrm{X}_{1}$ or $0.045 \%$ solution of maltotriose was incubated with the crystalline $\alpha$-glucosidase from $M$. javanicus $^{1,2)}$ having no isomaltose- or panosehydrolyzing activity, both $\mathrm{X}_{1}$ and maltotriose were completely hydrolyzed to glucose (Fig. 15). These results strongly suggest that $X_{1}$

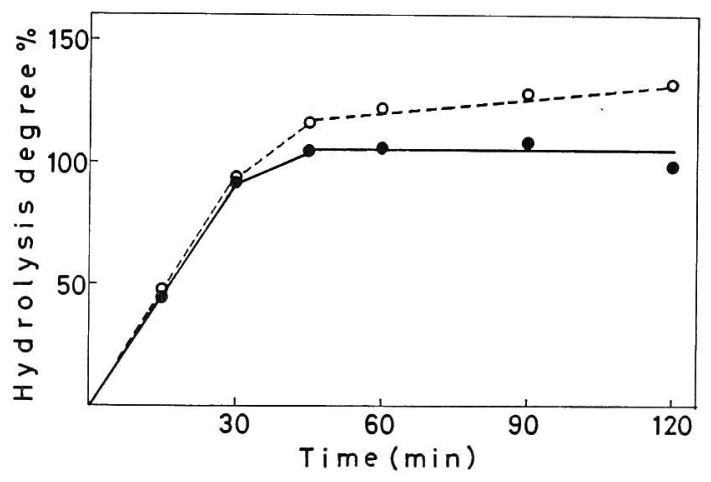

FIG. 15. Hydrolysis of Maltotriose and Substance $\mathrm{X}_{1}$ by Crystalline $a$-Glucosidase from $M$. javanicus.

The reaction mixture containing $15.16 \mu \mathrm{g}$ of crystalline $a$-glucosidase from $M$. javanicus, substrate (1305.6 $\mu \mathrm{g}$ as glucose), and $1.7 \mathrm{ml}$ of $0.1 \mathrm{M}$ acetate buffer, pH 5.3, in a final volume of $5 \mathrm{ml}$ was incubated at $37^{\circ} \mathrm{C}$.

- - maltotriose; O---O, substance $X_{1}$.

is maltotriose. Further investigations on the chemical structure of $\mathrm{X}_{1}$ are currently in progress in our laboratory. The enzyme catalyzed also the transfer of the $\alpha$-glucosyl residue from maltose to riboflavin (Fig. 7).

12) Inhibition studies. Among the metal ions tested, $\mathrm{Cu}^{2+}, \mathrm{Zn}^{2+}, \mathrm{Hg}^{2+}$, and $\mathrm{Ni}^{2+}$ were the potent inhibitors of the enzyme (Table III). No inhibition was observed with ethyl- 
TABle III. EfFect of Metal Ions

$0.04 \mathrm{ml}$ of enzyme solution ( 0.76 units), $0.02 \mathrm{ml}$ of $0.1 \mathrm{M}$ metal ion solution in deionized water, and $0.34 \mathrm{ml}$ of $0.05 \mathrm{M}$ phosphate buffer, $\mathrm{pH} 6.9$, were preincubated at $37^{\circ} \mathrm{C}$ for $30 \mathrm{~min}$, after which $0.1 \mathrm{ml}$ of $1 \%$ maltose was added, and the resulting mixture was kept at $37^{\circ} \mathrm{C}$ for $15 \mathrm{~min}$.

\begin{tabular}{lc} 
Metal ion & $\begin{array}{c}\text { Hydrolysis } \\
\text { (residual activity \%) }\end{array}$ \\
\hline None & 100 \\
$\mathrm{AlCl}_{3}$ & 124.1 \\
$\mathrm{BaCl}_{2} \cdot 2 \mathrm{H}_{2} \mathrm{O}$ & 66.1 \\
$\mathrm{CaCl}_{2} \cdot 2 \mathrm{H}_{2} \mathrm{O}$ & 86.8 \\
$\mathrm{CoCl}$ & 96.1 \\
$\mathrm{Cu}\left(\mathrm{CH}_{3} \mathrm{COO}\right)_{2}$ & 0 \\
$\mathrm{HgCl}_{2}$ & 0 \\
$\mathrm{KCl}$ & 117.1 \\
$\mathrm{MgCl}_{2} \cdot 6 \mathrm{H}_{2} \mathrm{O}$ & 100.4 \\
$\mathrm{MnCl}_{2} \cdot 4 \mathrm{H}_{2} \mathrm{O}$ & 129.2 \\
$\mathrm{NiCl}_{2} \cdot 6 \mathrm{H}_{2} \mathrm{O}$ & 17.3 \\
${\mathrm{~Pb}\left(\mathrm{CH}_{3} \mathrm{COO}\right)_{2}}_{\mathrm{ZnCl}}$ & 130.7 \\
\hline
\end{tabular}

Table IV. EFFECTS OF INHIBITORS AND VARIOUS CARBohydRATES

The reaction mixture containing $0.04 \mathrm{ml}$ of enzyme solution ( 0.76 units), $0.2 \mathrm{ml}$ of $0.1 \mathrm{M}$ phosphate buffer, $\mathrm{pH} 6.9$, each reagent dissolved in deionized water, and deionized water in a final volume of $0.4 \mathrm{ml}$ was preincubated at $30^{\circ} \mathrm{C}$ for $5 \mathrm{~min}$, after which $0.1 \mathrm{ml}$ of $1 \%$ maltose was added, and the resulting mixture was kept at $30^{\circ} \mathrm{C}$ for $15 \mathrm{~min}$.

\begin{tabular}{|c|c|c|}
\hline $\begin{array}{l}\text { Inhibitor or } \\
\text { carbohydrate }\end{array}$ & Concentration & $\begin{array}{l}\text { Hydrolysis } \\
\text { (residual } \\
\text { activity } \% \text { ) }\end{array}$ \\
\hline & $\mathrm{mm}$ & \\
\hline None & & 100 \\
\hline EDTA $^{a)}$ & 5 & 100 \\
\hline $\operatorname{PCMB}^{a}$ & 0.05 & 0 \\
\hline \multirow[t]{2}{*}{$\mathrm{DHT}^{a}$} & 0.04 & 0 \\
\hline & 0.004 & 26.8 \\
\hline \multirow[t]{3}{*}{ Rose bengal ${ }^{b}$, } & 0.1 & 12.0 \\
\hline & 0.01 & 22.6 \\
\hline & 0.001 & 60.2 \\
\hline \multirow[t]{2}{*}{ Tris } & 50 & 7.5 \\
\hline & 100 & 7.5 \\
\hline \multicolumn{3}{|l|}{$\alpha-\mathrm{D}-\mathrm{Glucose}-1-$} \\
\hline phosphate & 6.7 & 120.9 \\
\hline Maltitol & 7.3 & 100 \\
\hline Sucrose & 7.3 & 100 \\
\hline \multirow[t]{2}{*}{ Turanose } & 7.3 & 64.4 \\
\hline & 14.6 & 50.6 \\
\hline
\end{tabular}

a) Preincubation time: $30 \mathrm{~min}$.

b) Reaction mixture was preincubated for $30 \mathrm{~min}$ in the same procedure as described in the previous paper. ${ }^{2)}$ enediamine tetraacetate (EDTA). Tris and turanose inhibited $\alpha$-glucosidase activity (Table IV).

13) Amino acid residue of active center. On the basis of the results on the $\mathrm{pH}$ dependence of the enzymatic activity, the $\mathrm{p} K$ values were calculated to be approximately 6.0 and 8.3. The $\mathrm{p} K$ value 6.0 was considered to correspond to an imidazole group of the histidine residue and the other value 8.3 to a sulfhydryl group of the cysteine residue in proteins. Experiments were carried out with diazonium-1-H-tetrazole (DHT) and rose bengal, the specific modification reagents for the histidine residue, and $p$-chloromercuribenzoate (PCMB) for the cysteine residue. DHT was prepared in the same procedure as described in the previous paper. ${ }^{23}$ The three reagents just described acted as inhibitors of the enzyme (Table IV). PCMB showed no inhibitory effect on the enzymatic activity, when the enzyme was preincubated in the presence of $5 \mathrm{~mm}$ of mercaptoethanol. By the addition of $5 \mathrm{~mm}$ of mercaptoethanol to the enzyme solution, $35 \%$ of the activity of the enzyme which was inhibited by the preincubation with PCMB before the introduction of maltose, was restored.

\section{DISCUSSION}

An $\alpha$-glucosidase from the cells of $B$. cereus was prepared in a highly purified state by a procedure including crush with a french press, fractionation with ammonium sulfate, column chromatography on DEAE-cellulose and on DEAE-Sephadex A-25, and preparative polyacrylamide gel electrophoresis. The a-glucosidase gave a single protein band when examined by polyacrylamide disc gel electrophoresis, and showed a single boundary sedimentation pattern in the ultracentrifugal analysis. The enzyme was very different from $\alpha$-glucosidases from other origins in values of $s_{20, \mathrm{w}}^{0}$ and molecular weight, substrate specificity, and transglucosylation action. The $\alpha$-glucosidase had a sedimentation constant of $1.4 \mathrm{~S}$, corresponding to a molecular weight 
of 12,000 . Both physical values just described were much smaller than those of the glycosidases previously reported. The $\alpha$ glucosidase of $B$. cereus hydrolyzed strongly $\alpha-(1 \rightarrow 4)-$ and $\alpha-(1 \rightarrow 3)$-glucosidic linkages, and negligibly $\alpha-(1 \rightarrow 6)$ - and $\alpha$ - $(1 \rightarrow 2)$-glucosidic linkages. The $a$-glucosidases from plants $^{12 \sim 13)}$ and from $M$. javanicus ${ }^{21}$ hydrolyzed soluble starch, and the $\alpha$-glucosidases from animals $^{14 \sim 17}$ hydrolyzed glycogen, whereas the $a$-glucosidase from $B$. cereus did not hydrolyze these polysaccharides. The $\alpha$ glucosidase from $B$. cereus hydrolyzed phenyl $\alpha$-maltoside to glucose and phenyl $a$-glucoside, while that from Asp. niger ${ }^{18}$ hydrolyzed phenyl $\alpha$-maltoside to phenol and maltose, indicating that the former splits the $\alpha-(1 \rightarrow 4)$ glucosidic linkage between two glucosyl residues in phenyl $\alpha$-maltoside, whereas the latter splits first the linkage between phenol and maltosyl residue. The $a$-glucosidases from brewer's yeast ${ }^{19 \sim 41)}$ hydrolyzed phenyl $\alpha$-glucoside and sucrose faster than maltose, while the $\alpha$-glucosidase from $B$. cereus hydrolyzed phenyl $\alpha$-glucoside slower than maltose and showed no activity toward sucrose. The transglucosylation action of the $\alpha$-glucosidase from $B$. cereus was examined by paper chromatography. Two unknown substances $X_{1}$ and $X_{2}$ were detected on chromatograms as the transglucosylation products from maltose at a concentration of 5 per cent. $X_{1}$ was presumed to be maltotriose from the similarities in the chromatographic mobility and in the rate of hydrolysis with the crystalline $\alpha$ glucosidase from $M$. javanicus which was not capable of hydrolyzing isomaltose or panose. Studies on $\mathrm{X}_{2}$ have not yet been undertaken because of its scanty amount isolated. Isomaltose was detected as the main transglucosylation product from maltose digests with the $\alpha$-glucosidases from Asp. niger, ${ }^{18)}$ Asp. oryzae, ${ }^{25)}$ Penicillium chrysogenum ${ }^{26 !}$ and Schizosaccharomyces pombe. ${ }^{27)}$ Like other glycosidases, ${ }^{1,28,31)}$ the $\alpha$-glucosidase from $B$. cereus catalyzed the transfer of the $\alpha$-glucosyl residue of maltose to riboflavin.

Finally, we examined the amino acid resi- dues of the active center by the techniques of the specific modification. From the results, it is inferred that both histidine and cysteine residues in the active center are closely related to the activity of the $\alpha$-glucosidase from $B$. cereus.

Acknowledgement. The authors wish to express their gratitude to Mr. K. Masuda of the Research Laboratory, Hayashibara Co., Ltd. for his technical assistance on identification and also to Mr. M. Fujiwara of the Animalize's Judgement Station of Okayamaken for his examination on pathogenicity of the isolated strain of Bacillus.

The authors are very grateful to Professor J. Ozawa of the Institute for Agricultural and Biological Sciences, Okayama University, for his encouragement.

\section{REFERENCES}

1) Y. Yamasaki, T. Miyake and Y. Suzuki, Agr. Biol. Chem., 37, 131 (1973).

2) Idem, ibid., 37, 251 (1973).

3) K. Nisizawa and Y. Hashimoto, "The Carbohydrates," Vol. II A, ed. by W. Pigman and D. Horton, Academic Press, New York, 1970, p. 241.

4) N. M. Papadopoulas and W. C. Hess, Arch. Biochem. Biophys., 88, 167 (1960).

5) A. Dahlquist, Biochem, J., 80, 547 (1961).

6) O. Folin and V. Ciocalteu, J. Biol. Chem., 73, 627 (1927)

7) O. Warburg and W. Christian, Biochem. Z., 310, 384 (1941).

8) B. J. Davis, Ann. N.Y. Acad. Sci., 121, Art. 2, 404 (1964).

9) D. E. Williams and R. A. Reisfeld, ibid., 121, Art. 2, 373 (1964).

10) K. Weber and M. Osborn, J. Biol. Chem., 244, 4406 (1969).

11) D. H. Huston and D. J. Manners, Biochem. J., 94, 783 (1965).

12) M. Takahashi and T. Shimomura, Agr. Biol. Chem., 32, 929 (1968).

13) N. Takahashi, T. Shimomura and S. Chiba, ibid., 35, 2015 (1971).

14) H. N. Torres and J. M. Olavarria, J. Biol. Chem., 239, 2427 (1964).

15) C. B. Bruni, F. Auricchio and I. Covelli, ibid., 244, 4735 (1969).

16) T. N. Palmer, Biochem. J., 124, 713 (1971).

17) K. Fujimori, T. Fukui and Z. Nikuni, Agr. Biol. Chem., 36, 483 (1972).

18) Y. Tsujisaka and J. Fukumoto, Nippon Nógeikagaku Kaishi, 37, 747 (1963).

19) A. Gottschalk, "The Enzymes," Ist ed., Vol. I, Part I, ed. by J. B. Sumner and K. Myrbäck, 
Academic Press, New York, 1950, p. 551.

20) H. Baumann and W. Pigman, "The Carbohydrates," ed. by W. Pigman, Academic Press, New York, 1957, p. 562.

21) A. H. Cook and A. W. Phillips, Arch. Biochem. Biophys., 69, 1 (1957).

22) A. W. Phillips, ibid, 80, 346 (1959).

23) H. Halvorson and E. Ellias, Biochim. Biophys. Acta, 30, 28 (1958).

24) S. Chiba, S. Sugawara, T. Shimomura and $Y$. Nakamura, Agr. Biol. Chem., 26, 787 (1962).

25) S. Sugawara, Y. Nakamura and T. Shimomura,
Bull. Agr. Chem. Soc. Japan, 24, 281 (1960).

26) K. Saroja, R. Venkataraman and K. V. Giri, Biochem. J., 60, 399 (1955).

27) S. Chiba and T. Shimomura, Agr. Biol. Chem., 30, 536 (1966).

28) Y. Suzuki and K. Uchida, Vitamins (Japan), 41, 338 (1970).

29) Y. Suzuki and K. Uchida, ibid., 46, 105 (1972).

30) Y. Suzuki, K. Uchida and A. Mino, ibid., 42, 324 (1970).

31) Y. Suzuki, T. Miyake, K. Uchida and A. Mino, ibid., 47, 259 (1973). 